Paedagogia Christiana

$2 / 46$ (2020) - ISSN 1505-6872

DOI: http://dx.doi.org/10.12775/PCh.2020.016

Ben Lazare Mijuskovic*

ORCID: 0000-0001-9647-6609

Los Angeles, USA

\title{
The Role of Empathy as a Path to Intimacy
}

\section{Rola empatii jako drogi do intymności}

\begin{abstract}
The fear of absolute loneliness is the universal drive in all human beings. The opposite of loneliness is intimacy. Both are intense modes of human consciousness. Intimacy is secured through empathy, which is based on a mutual relationship of shared trust, respect and values, as well as a mutual sharing of feelings, meanings and affection. The dynamics of both intimacy and empathy - unlike sympathy and pity - must be mutual; whether it is expressed between two human beings, or between a person and the Lord through the power of prayer.
\end{abstract}

Keywords: loneliness; separation; intimacy; empathy; self-consciousness; intentionality; free will; faith; Kant; Husserl; Freud.

Abstrakt: Strach przed absolutnym osamotnieniem stanowi powszechny motyw ludzkiego działania. Przeciwieństwem osamotnienia jest intymność. Tak jedno, jak i drugie stanowią dominanty ludzkiej świadomości. Intymność, możliwa dzięki empatii, opiera się na wzajemnym zaufaniu i szacunku; na współdzielonych wartościach, uczuciach, znaczeniach i przywiązaniu. Dynamika bliskości i empatii w przeciwieństwie do współczucia i litości - musi być wzajemna; zarówno w relacji dwojga ludzi, jak i człowieka i Boga dzięki sile modlitwy.

* Prof. dr. Ben Lazare Mijuskovic, California State University at Dominguez Hills, USA; email: ruthben@roadrunner.com. 
Słowa kluczowe: osamotnienie; rozłąka; intymność; empatia; samoświadomość; intencjonalność; wolna wola; wiara; Kant; Husserl; Freud.

In the following paper, I wish to discuss four themes: (1) that all human beings are innately lonely, as this loneliness is the universal existential condition of humanity; (2) why this is so, which involves a theory of consciousness; (3) the consequences of loneliness; and (4) its remedies.

Current research claims that loneliness is passively caused by external conditions: familial, environmental, cultural, situational, and even chemical imbalances in the brain; hence, it is transient, avoidable and curable. By contrast, I argue that loneliness is constituted by the innate activities of reflexive self-consciousness (Kant, 1958) and transcendent intentionality (Husserl, 1962), and is therefore permanent, unavoidable and incurable - although it can be mitigated.

According to Kant, the creative, productive and 'spontaneous' acts of consciousness are responsible for the formation of the transcendental relational categories, immanent time-consciousness, and the unity of self-consciousness (Kant, 1958). For Husserl, similarly, the spontaneous acts result in producing the intentional, purposive quality of consciousness (Husserl, 1962). Together, these dual a priori synthetic acts constitute the universal and necessary elements required for human awareness. As in Feuerbach, the subject projects itself outwardly, only to return to its self self-consciously.

After the biological needs for air, water, nourishment and sleep are met, the needs both to avoid loneliness and to secure intimacy are the most powerful motivational instincts and drives in human consciousness. Loneliness results from a deep sense of separation - both emotionally and cognitively as it surfaces in various forms during our early periods of human development and continues throughout the rest of our lives. Basically, there are six distinguishable forms of separation in human consciousness: (1) object-object separation during birth; (2) self-object separation, which is intrapsychic; (3) subject-subject separation, which is interpersonal; (4) self/self-alienation, which arouses a psychotic reaction in response to intense or unduly prolonged periods of loneliness; (5) self-value separation, including self-God estrangement; and (6) life-death separation (Mijuskovic, 2012, 2015b, 2018).

The sense of separation begins with birth, when the foetus is physically removed from the mother's womb (biological object-object separation). 
The ego sees itself deserted by all protective forces and lets itself die. Here is the same situation as that which underlay the first great anxiety-state of birth and the infantile anxiety of longing [i.e. loneliness] - the anxiety due to separation from the protective mother. (Freud, 1960)

Loneliness engenders and exhibits two very different but closely related emotions, drives and instincts: both anxiety and hostility. However, in the newborn infant, it begins with a form of 'unconscious' depression, an 'involuntary' withdrawal from life. This phenomenon was first observed during a phase of unusual circumstances regarding cases of serious infant neglect. It was noticed that when infants are left unattended for extended periods of time, deprived of emotional nurturance, severe developmental regressions involving both biological and intellectual deficiencies can occur. Over the years, clinical diagnoses of marasmus, hospitalism and anaclitic depression have been given in these circumstances.

During the first year of life, when there is a 'wasting away' in the infants, the disorder occurs with no apparent organic basis; the babies with marasmus become apathetic and listless, showing considerable functional disorientation. The infants' interest in surrounding events declines, as does the intake of food and water. Their bodies drop weight and radically declines; death may follow. Indeed, at the close of World War I, marasmus was held accountable for half the deaths of babies under the age of one. During this period, infants were closely studied in these situations of virtually forced neglect in England; I say 'forced' because the mothers had been recruited to work in military factories in order to help with the war effort.

The aforementioned research found that in the first year of life, the sum total of the baby's human relations, and nearly all its sensory perceptions, take place through the mother. Losing the mother in the first year of life severely limits the child's emotional and neuromuscular development. Even if a later attempt is made to correct the loss, lasting damage can only be avoided if the emotional deprivation is held within narrow limits. At first the studied infants became tearful, showing a conflict between disappointment at the approach of a stranger and the craving for human contact. Later they became withdrawn and rejected any approach. Towards the end of the third month, their facial expressions became rigid, screaming subsided, as did weeping; and the children presented eating and sleeping difficulties, lying mostly prone and non-responsive in the crib. The periods of separation varied from five to twelve months, and the children showed progressive degrees of physical and mental deterioration (Ruch, 1953; Spitz, 1945, 1946). 
If the loneliness becomes intense or unduly prolonged, it will lead to a retreat, a regression back towards the womb, frequently ending in death. As stated above, half the children below one year of age succumbed.

The second stage of separation occurs between the ego and inanimate objects (subject-object separation). The self and the concept of the object mutually constitute each other within self-consciousness, basically it's a form of intrapsychic separation. (Kant, 1958)

Freud describes a comparable psychological development:

Further reflection tells us the adult's ego-feeling cannot have been the same from the beginning. It must have gone through a process of development, which cannot be demonstrated but which admits of being reconstructed with a fair degree of probability. An infant at the breast does not as yet distinguish his ego from the external world as the source of the sensations flowing in upon him. He gradually learns to do so, in various promptings. He must be very strongly impressed by the fact that some sources of excitation, which he will later recognise as his own bodily organs, can provide him with sensations at any moment, whereas other sources evade him from time to time - among them what he desires most of all, his mother's breast - and only reappear as a result of his screaming for help. In this way there is for the first time set over an 'object' in the form of something which exists 'outside' and which is only forced to appear by a special action... Originally the ego includes everything, later it separates off an external world from itself. Our present ego-feeling is, therefore, only a shrunken residue of a much more inclusive - indeed, an all-embracing - feeling which corresponds to a more intimate bond between the ego and the world about it. If we may assume that there are many people in whose mental life the primary ego-feeling has persisted to a greater or lesser degree, it would exist in them side by side like a counterpart to it. In that case the ideational contents appropriate to it would be precisely those of a limitless bond with the entire universe - the same ideas with which my friend elucidated the 'oceanic feeling'. (Freud, 1961)

Several comments are warranted. First, this separation between subject and object is the infant's first recognition of a distinction between its self and a recalcitrant external world of physical objects; a world, however, that has certain desirable objects, namely the mother's breast - something to be demanded and fought for (Hegel, 1977). This is the first instance of a self-con- 
scious act of valuation. The infants distinguish and recognise desirable objects from irrelevant ones. Secondly, the 'oceanic feeling' promotes a delusional fantasy that the infants are omnipotent, completely self-sufficient; they are the sum total of reality, and they are their own universes. 'We have said that the ego is the heir to the original narcissism in which the childish ego enjoyed self-sufficiency' (Freud, 1959). This dynamic is extremely important because it anticipates the egotistic and narcissistic tendency towards aggression in the child. The child has learned to scream, fuss, and complain when it is not pampered and indulged. This is the origination of entitlement issues. Whereas in the first separation, the infant unconsciously regressed back toward death, this older child will attack the mother and siblings with ferocity and anger when he/she fails to achieve what he/she desires. (St Augustine gives the example of two babes suckling at their mother's breast; and when one has had enough, he/she still tries to prevent his/her sibling from imbibing.) The infants realise that if they scream and cry, certain demands are often met. This constitutes the stage of primary narcissism, psychologically speaking - and theologically, I suppose, this is where egoism and pride symbolise man's 'first sin'. In addition, the infants realise that the breast 'belongs'; it is under the control of an other self-conscious being, who has the freedom and the power over them to either offer or deny them what they desire. As Hegel dialectically describes it, the early developmental stages of human consciousness progresses through several cognitive stages: the immediacy of Sense-Certainty; the mediacy of Perception; then reflexive Self-Consciousness, which is followed by the Lordship and Bondage conflict, when the selves realise that they are engaged in a struggle between two egos - in this case the self and the mother. It is a battle to the death for recognition, for freedom over and against the other self; it is a struggle to have one's own desires prevail over the desires of the other self (Hegel, 1977).

As Freud adds:

We have given it the name of 'narcissism.' The subject behaves as though he were in love with himself; his egoistic instincts and his libidinal desires are not yet separable under our analysis... We suspect already that this narcissistic organisation is never wholly abandoned. A human being remains to some extent narcissistic even after he has found external objects for his sexual instincts. (Freud, 1950)

The first article written on loneliness, as a subject in its own right, is by Gregory Zilboorg, a psychoanalyst (Zilboorg, 1938). In the article, he draws 
a Kantian 'synthetic a priori', i.e. an intrinsic relationship, between narcissism $<>$ loneliness $<>$ hostility, thus indicating a universal and necessary $d e-$ velopmental connection between loneliness and hostility. At first, according to Zilboorg, the self-conscious ego's response to loneliness is aggression, hostility. But when the infants outburst, their 'acting-out' dynamics are unsuccessful, anxiety follows; only then are they followed by depression and the withdrawal from others, as the interpersonal separations continues. Often we equate depression with sadness, and we miss that it is fraught with hostility - anger with others and with the self.

The extremes of dysfunctional narcissism are constituted by the ego's identification with its own self-conscious feelings, with its own burgeoning symptoms of megalomania, omnipotence, entitlement issues, aggressive and self-destructive motivations; thus, when they become apparent, severe psychiatric disorders will surface (Narcissistic Personality Disorder 301.81 and Antisocial Personality Disorder 301.7, Diagnostic and Statistical Manual of Psychiatric Disorders). Zilboorg, of course, is writing his article in 1938, the year before Hitler and the German military invaded the Czechoslovakian Sudetenland. But both Zilboorg (1938) and Arendt (1976) affirm that loneliness, narcissism and aggression are intrinsically related and the direct outcome of an enforced solitude; furthermore, they extend their psychological principle of narcissistic condemnation to include not only individuals, but also groups and nations.

According to Zilboorg (1938), if the sense of loneliness and the threat of ultimate separation from others seems irrevocable, in extreme cases, the ego will turn against both the world and even its self. It can also become self-alienated, psychotic, delusional and hallucinatory by an internal splitting within its own self: i.e. self/self-alienation (Hegel, 1971). Zilboorg further observes that it is not uncommon for murder and/or suicide to follow. And when experts and criminologists are puzzled by the 'motivations underlying' domestic violence cases, generally the animating motive consists in feelings of intolerable and unsustainable loneliness, feelings of rejection, abandonment, betrayal, etc.

Self-value separation occurs when an individual experiences the loss of a cherished value, a reason to live, something which makes life meaningful or purposeful; values which can span the spectrum from self-indulgence to altruism, from wealth to fame, from pleasing oneself to pleasing others. What unifies and solders human relationships are values such as friendship, marriage, family, religion, etc. But I will postpone for the moment discussing the sense of separation experienced in the special case of feared religious 
separation, i.e. estrangement from God (e.g. Kierkegaard). And I suppose we could also refer to Marx's concept of proletarian economic alienation as primarily social.

In Freudian terms, the essence of separation is symbolised by the god of Death (Thanatos), whereas the essence of unity is symbolised by the goddess of love (Eros).

Intimacy. The opposite of loneliness is intimacy. It is not love: I can love a person, but they might not love me. However, loneliness can be conquered whenever our values are so strong that they are sufficiently connected to a personal ideal, virtually an obsessional ideal; or when they can be shared by and with other self-conscious selves. But this can only be accomplished if there are intimately shared feelings, meanings and values with other self-conscious beings, or with Being itself. The essence of intimacy is internally constituted - not externally caused - by (a) mutual trust; (b) mutual affection; and (c) mutual respect between age-appropriate or status-appropriate beings or with a Being, e.g. child to parent, or human being to God. Intimacy also presupposes the mutual sharing of feelings (affection); meanings (communication); and above all, the commitment of fidelity towards the other being. Unless the mutuality is expressed on both sides, intimacy is severely limited or non-existent (Mijuskovic, 1991).

Philosophers distinguish between primary qualities, i.e. matter and motion that exist independently of the mind; secondary qualities relating to the five senses, as well as feelings, which are subjective and vary from person to person; and tertiary qualities, which deal with values. Only human beings create values, such as of goodness and evil, beauty and ugliness, courage and cowardice, altruism and egoism, etc. No other creature in the animal kingdom creates values. Values are critical because all human beings guide their lives according to the values they have created. Values are created freely and they can be changed. Intimacy is a value; it is a choice over loneliness.

What is at stake in intimacy is mutuality. In the case of a married couple, the possible mutuality is obvious and natural, and it is usually co-equal. In the age-appropriate case of a father and his son, they must trust, respect, and like each other. In the case of a human being and God, the situation is more complex. A person cannot directly reach the transcendent essence of God; this requires a secondary communicative mediation. Specifically, it is mediated by Christ's suffering on the Cross. A person's fear of estrangement from God, the fear of abandonment, is transmitted through Christ, who is both human and divine. As Christ sacrificed himself for the love of humanity, so must people sacrifice themselves for the sake of others. The connection, 
of course, is that Christ empathises with human loneliness and people empathise with Christ's suffering (Kierkegaard).

Empathy. The path to intimacy is through empathy. Unfortunately, today the term 'empathy' is misused and virtually identified with 'sympathy', and even confused with 'pity'. Originally the term was coined by Theodor Lipps, with an aesthetic meaning as opposed to an ethical meaning. According to Lipps (1979), the essence of empathy is achieved by the ego's projection of its subjective feelings, meanings and values into the aesthetic object (Einfühlung). The aesthetic object consists in a 'sensuous appearance'; however, it is not merely a bare physical object, but rather it is an image - it is an artistic creation of the imagination, a spontaneous expression, which becomes moulded within the contemplator's free imagination as it becomes charged and fused with expressive feelings, meanings and values. It becomes the beautiful thing contemplated as the projection is directed outwardly, beyond the self, intentionally, phenomenologically, towards the receptive object and absorbed therein. Nevertheless, what gives aesthetic meaning to the object, and what constitutes the ground of its enjoyment, is the act of contemplation. The mind unconsciously enlivens the outward form of a dancer by fusing into it the modes of the observer's own activity - its striving and willing, its sense of freedom and power, its grace, balance and rhythm. The moods thus projected are transported into the object, but they do not express either a utilitarian or an ethical import. Rather, they are purely contemplative, 'disinterested.'

First there is the inner activity - the emotion of pride, the feeling of freedom and vigour; second there is the external sensuous content as bare physical stimulus. The aesthetic object springs into existence as a result of a fusion of the two factors. The ego supposes itself to be a unity with the object and there is no longer any duality. Empathy means the twofold disappearance of a separation between the subject and the object, and the enrichment of the aesthetic experience that results from this interpenetration is so completely transported into the object that the contemplator of a dancer may unconsciously imitate their posture and movements by muscular adjustments (Lipps, 1979).

But the problem is that the projected exchange is not mutual, nor is it interpersonal; it is merely intrapsychic. The relation between the subject pole and the object pole remains unfulfilled and they are not mutually recognised. The relation between the observer and the dancer is one-sided.

The problem that needs to be addressed is to what extent can we presume to think - believe? - that we can know the mind of another self-con- 
scious being, either animal, human, or divine? If we assume empathy, the implications are that in some significant sense we know that we are meaningfully communicating, sharing feelings and thoughts with an other self; that both of us are reflexively self-conscious of the other self, of each other; that we not only know our own thoughts but also have the capacity to know the thoughts, have insights, understanding and knowledge of the thinking of the other being - or Being.

In a general sense, this was the problem of solipsism that confronted Edmund Husserl in his Cartesian Meditations; first, how can I prove there are other thinking selves? Second, how much can I know about what they are feeling and thinking? Empathy assumes that I know how the other person feels and what he/she is thinking. But how can I establish an intersubjective connection and communication (Husserl, 1973; Spiegelberg, 1965). How can I know someone else's mind? How can I 'know' what God wants of me?

It is at this point that Husserl turns to Lipps' concept of empathy. I must be able to 'move' from the immanency of my own ego to that of the other self; to within his/her consciousness. We recall Descartes's proof that the self exists: 'I think = I exist,' the cogito, which he borrows from St Augustine's Contra Academicos (Mijuskovic, 1970). But Husserl is also asking: how can I phenomenologically establish 'an ultimate community of Leibnizian monads?' (p. 107). In his attempt, he provides the following presumably eidetic description. Empathy, he asserts, is a form of 'mirroring' the physical, the bodily presence of the other self (p. 94); but mirrors are not self-conscious. Secondly, he argues that empathy is an inferential way of placing my body as if it were in the other's physical space; as a mediate twofold 'appresentation'; as an 'analogical apperception' - this is like pretending to be where I am not (p. 108). But any phenomenological insight, in order to be true, must be grasped directly, intuitively, immediately; and none of Husserl's examples comply with that principle. The result is that he fails, as Lipps had before him. His empathy is as one-sided as Lipps' had been.

Empathy must be mutual and reciprocal, as previously indicated. Consider the following situation: imagine a young couple experiencing the death of their infant child by drowning. The grief experienced, the tragedy, the sense of irrevocable loss is mutual, shared by both equally and intimately. Both feel and know how the other feels and suffers. Or imagine an elderly couple having spent a lifetime of mutual love and support, learning one day that one of them is diagnosed with terminal cancer. Their grief is mutual and shared.

Why is this intimate relation so important? Because empathy is the path, the means of attaining intimacy. Remember, intimacy is grounded in mutual 
trust; in mutual age-appropriate or status-appropriate respect when making decisions regarding, most importantly, the ethical and religious values shared by the two selves. The mutual conviction must be in the same value. When these conditions are met between two self-conscious selves, loneliness is vanquished and intimacy achieved.

In its deepest throes, loneliness is intense; it can lead the soul to destroying others and to self-destruction. Correspondingly, intimacy needs to be equally intense and sustained. It is grounded in continuous empathetic communication and faithful commitment to an other self or Self. It exhibits aspects of a religious unity between two dedicated selves when the value is reciprocally shared.

Immanuel Kant, in the Critique of Practical Reason (1956), formulates his categorical imperative, his moral command. Its last two expressions stipulate that you should 'Always treat the other person as if he/she had infinite worth and value and never as a means to further your own utilitarian or selfish ends.' Basically, it means putting the other person's interest ahead of your own. When each one pursues this principle empathically regarding the other self, then intimacy will have been achieved. The third formulation is, 'Whenever you formulate the moral law and you follow your own law, you are free.' As I say, this is a very high standard.

Religious intimacy. The extreme intensity of loneliness, and the possible sense of abandonment by a separation from God, is perhaps most frightening. Christian values are grounded in four assumptions: (a) the beneficence, the goodness of God (St Augustine's, St Anselm's and Descartes' ontological 'intuition'); (b) the freedom of the will; (c) faith (Tertullian, St Augustine, St Anselm, Pascal, Kierkegaard); and (d) the immortality of the human soul. None of the ancient Greek philosophers, nor the Pre-Socratics, Plato, or Aristotle - nor any of the Hellenistic thinkers, the Stoics, Epicureans, or Sceptics - posit free will and/or faith. So how might empathy and intimacy function in a Christian context?

St Augustine is the most insightful of the Christian thinkers. He formulates the 'problem of evil': why is there evil in the world if God is omnipotent, omniscient and omnibenevolent? And he answers that evil is a negation, nothing in-itself; an absence just as darkness is the absence of light. He defines the freedom of the will as a faculty above the intellect and faith, as the power to grasp truths beyond reason: 'I believe so that I may understand.' Faith also provides for his conversion from Manichean materialism to a dualistic theism. But he also recognises the evil in man; such as his own narcissism and egoism. He recounts an incident from his childhood, when he 
and several children stole into a fruit orchard and maliciously destroyed the fruit - evil for evil's sake.

The sense of loneliness can be intense, and the sense of abandonment by God is the worst sentence a human being can experience. To continue to exist absolutely alone forever is the worst fate imaginable. Witness the prayer of St Augustine, the plea for salvation that can only be assuaged through a relation of complete intimacy with God.

Who will give me help, so that I may rest in you? Who will help me, so that you can come into my heart and inebriate it, to the end that I may forget my evils and embrace you, my one good? What are you to me? Have pity on me, so that I may speak! What am I myself to you that you command me to love you and grow angry and threaten me with mighty woes unless I do? Is it but a small affliction if I do not love you? Unhappy man that I am, in your mercy, O Lord my God, tell me what you are to me. Say to my soul: I am your salvation. Say this, so that I may hear you. Behold, my heart's ears are turned to you, O Lord, open them, and say to my soul: I am your salvation. (Augustine, 1959)

In this exchange, clearly the intimacy is status-appropriate; it is a person's relation to God. Augustine believes as an article of faith that he is communicatively sharing mutual values with a supremely self-conscious and caring God. His faith and free will convince him that his pleas will not go unanswered.

In our previous discussion of the virtues of empathy as an essentially sharing process, we emphasised that it had to be mutual; we also indicated that, as in the instance of a child and a father, the twin commitments have to be mutually age-appropriate; correspondingly, in the case of God and man, it has to be status-appropriate, i.e. ontologically appropriate. Augustine's prayer is an empathetic form of communication, seeking an intimate sharing of values with God.

Like St Augustine, Kant refers to a 'terrifying sublime' religious experience. Kant never quotes authors in his writings; yet in an incredibly special instance, he was clearly so deeply moved by a spiritual vision that he was impelled to comment on a magazine article concerning his own religious convictions. 'I will only provide an example of the noble dread which the description of a total solitude can inspire and for this I will extract several passages from the merchant Carazan's dream in the Bremen Magazin.' 
The more his riches had grown, the more did this miserly rich man bar his heart to compassion and the love of others. Meanwhile, as the love of humankind grew cold in him, the diligence of his prayers and religious devotions increased. After this confession, he goes on to recount: One evening as I did my sums by my lamp and calculated the profit of my business, I was overcome by sleep. In this condition I saw the angel of death come upon me like a whirlwind and he struck me before I could plead against the terrible blow. I was petrified when I became aware that my fate had been cast for eternity and that to all the good I had done, nothing could be added and from the evil I had done nothing could be subtracted. I was led before the throne of he who dwells in the third heaven. The brilliance that flamed before me spoke to me thus. Carazan, your divine service is rejected. You have closed your heart to the love of humankind and held on to your treasures with an iron hand. You have only lived for yourself and hence in the future you shall also live alone and excluded from communion with the entirety of creation for all eternity. In this moment I was led away by an invisible force and driven through the shining edifice of creation. I quickly left innumerable worlds behind me. As I approached the most extreme limit of nature, I noticed that the shadows of the boundless void sank into the abyss before me. A fearful realm of eternal silence, solitude and darkness. Unspeakable dread overcame me at this sight. I gradually lost the stars from view and finally the last glimmer of light was extinguished in the most extreme darkness. The most extreme terror of despair increased with every moment, just as every moment my distance from the last inhabited world increased. I reflected with unbearable anguish in my heart that if ten thousand years were to carry me further beyond the boundaries of everything created, I would still see forward into the impenetrable abyss of darkness without hope or help of return - In this bewilderment I stretched my hands out to actual objects with such vehemence that I was thereby awakened. And now I have been instructed to esteem human beings, for even the least of them, whom in the pride of my good fortune I had turned away from my door would have been more welcome to me in that terrifying desert than all the treasures of Golconda. (Kant, 2011)

This amazing passage shows the poignancy of the emotional dimension of Kant's faith. Reason alone was insufficient to address the depth of the ultimate question regarding the meaning of human existence. Thus, as he declares: 'I have, therefore, found it necessary to deny knowledge in order to make room for faith' (1958). A similar experience of anguish is recorded in Descartes's Three Dreams (Poulet, 1956). 
Finally, life-death is the separation and the end of the relation between people and the world. All values are a choice; some choices are important and others relatively unimportant. But all values are born of human freedom. Freedom and loneliness are intrinsic to the human condition.

\section{References}

Arendt, H. (1976). The Origins of Totalitarianism. New York: Harcourt.

Augustine (1959). The Confessions. Trans. J. K. Ryan. New York: Doubleday and Co. Freud, S. (1950). Totem and Taboo. Trans. J. Strachey. New York: W. W. Norton.

Freud, S. (1959). Group Psychology and the Analysis of the Ego. Trans. J. Strachey. New York: W. W. Norton.

Freud, S. (1960). The Ego and the Id. Trans. J. Riviere. New York: W. W. Norton.

Freud, S. (1961). Civilization and Its Discontents. Trans. J. Strachey. New York: W. W. Norton.

Hegel, G. W. F. (1971). Philosophy of Mind. Trans. W. Wallace. Oxford: Clarendon Press.

Hegel, G.W. F., (1977). Phenomenology of Spirit. Trans. A. V. Miller. Oxford: Clarendon Press.

Husserl, E. (1962). Ideas: General Introduction to Pure Phenomenology. New York: Collier Books.

Husserl, E. (1973). Cartesian Meditations. An Introduction to Phenomenology. Trans. D. Cairns. The Hague: Matinus Nijhoff.

Kant, I. (1956). Critique of Practical Reason. Trans. L. W. Beck. New York: Bobbs-Merrill.

Kant, I. (1958). Critique of Pure Reason. Trans. N. Kemp Smith. London: MacMillan and Co..

Kant, I. (2011). Observations on the Feeling of the Beautiful and Sublime and Other Writings, P. Frierson \& P. Guyer (Eds.). Cambridge, 2011.

Lipps, T. (1979). Empathy, Inner Imitation, and Sense-Feelings. In M. Rader (Ed.), A Modern Book of Esthetics (pp. 371-378). New York: Holt, Rinehart, and Winston.

Mijuskovic, B. (1970). Descartes's Bridge to the External World: The Piece of Wax. Studi Internazionali di Filosofia, 3, 65-81. https://doi.org/10.5840/StudIntFil1971322

Mijuskovic, B. (1991). Intimacy and Loneliness. Journal of Couples Therapy, 1(3-4), 39-48. https://doi.org/10.1300/J036v01n03_04 
Mijuskovic, B. (1979-1980). Loneliness and Narcissism. Psychoanalytic Review, 66 (4), 479-492.

Mijuskovic, B. (2012). Loneliness in Philosophy, Psychology, and Literature. Bloomington, IN: iUniverse.

Mijuskovic, B. (2015a). Cognitive and Motivational Roots of Universal Loneliness. In A. Sha'ked \& A. Rokach, Addressing Loneliness: Coping, Prevention and Clinical Interventions (pp. 20-33). New York: Routledge.

Mijuskovic, B. (2015b). Feeling Lonesome: The Philosophy and Psychology of Loneliness. Santa Barbara, CA: Praeger.

Mijuskovic, B. (2018). Consciousness and Loneliness: Theoria and Praxis. Leuven: Brill Publishers.

Poulet, G. (1956). Studies in Human Time. Trans. E. Coleman. Baltimore: Johns Hopkins Press.

Ruch, F. (Ed.). (1953). Psychology and Life. Chicago: Scott, Foresman.

Spiegelberg, H. (1965). The Phenomenological Movement: A Historical Introduction. The Hague: Martinus Nijhoff, 1965.

Spitz, R. (1945). Hospitalism: An Inquiry into the Genesis of Psychiatric Conditions in Early Childhood. Psychoanalytic Study of the Child, 1, 53-74.

Spitz, R. (1946). Hospitalism: A Follow Up Report. Psychoanalytic Study of the Child, 2, 113-117.

Zilboorg, G. (1938). Loneliness. Atlantic Monthly, February, 45-54. 